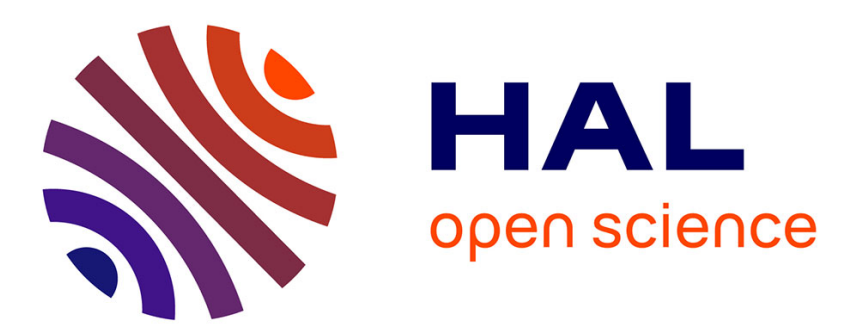

\title{
Comments on "Direct Calculation of minimum set of inertial Parameters of Serial Robots"
}

\author{
Wisama Khalil, Fouad Bennis
}

\section{To cite this version:}

Wisama Khalil, Fouad Bennis. Comments on "Direct Calculation of minimum set of inertial Parameters of Serial Robots". IEEE Transactions on Robotics and Automation, 1994, 10 (1), pp.78-79. hal-00401750

\author{
HAL Id: hal-00401750 \\ https://hal.science/hal-00401750
}

Submitted on 6 Jul 2009

HAL is a multi-disciplinary open access archive for the deposit and dissemination of scientific research documents, whether they are published or not. The documents may come from teaching and research institutions in France or abroad, or from public or private research centers.
L'archive ouverte pluridisciplinaire HAL, est destinée au dépôt et à la diffusion de documents scientifiques de niveau recherche, publiés ou non, émanant des établissements d'enseignement et de recherche français ou étrangers, des laboratoires publics ou privés. 


\title{
Comments on "Direct Calculation of Minimum Set of Inertial Parameters of Serial Robots" \\ W. KHALIL, F. BENNIS \\ Laboratoire d'Automatique de Nantes URA C.N.R.S. 823 \\ Ecole Centrale de Nantes/université de Nantes \\ 1 Rue de la Noë \\ 44072 NANTES CEDEX \\ FRANCE \\ khalil@lan.ec-nantes.fr
}

\begin{abstract}
The paper presented by Gautier and Khalil [1] gives a direct and efficient method to calculate most of the minimum inertial parameters of serial robots. Some parameters concerning the translational links between the first rotational joints which are not parallel need particular calculation, partial results concerning the case where these links are either perpendicular or parallel are given in the paper [1]. This correspondence presents a direct solution to this particular case, such that all the minimum inertial parameters can be obtained directly without calculating the energy or the dynamic model of any link.
\end{abstract}

\section{I- Calculation of the minimum inertial parameters}

The minimum inertial parameters can be calculated from the standard inertial parameters by eliminating the parameters which have no effect on the dynamic model and those which can be regrouped to some others. The expression of the total energy (potential +kinetic) which is linear in the inertial parameters can be used to determine these parameters, it can be seen that the energy of the robot is given as:

$$
\mathrm{H}=\sum_{\mathrm{j}=1}^{\mathrm{n}} \mathbf{h}^{\mathrm{j}} \mathbf{X}^{\mathrm{j}}
$$

where: $\mathbf{X}^{\mathrm{j}}$ represent the standard inertial parameters of link $\mathrm{j}$, and $\mathbf{h}^{\mathrm{j}}$ contains the coefficients of the inertial parameters in the energy expression.

It can be seen that [1]:

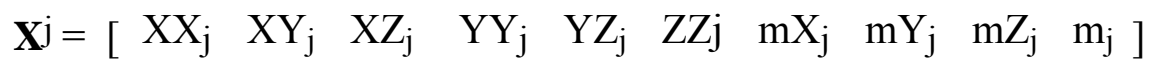

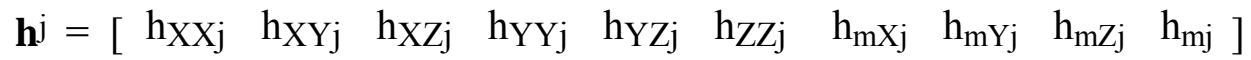

The expressions of the elements of $\mathbf{h}^{\mathrm{j}}$, can be found in [2].

Based on relation (1) the following results can be given:

a- An inertial parameter $X_{i}$ has no effect on the dynamic model if: 


$$
\mathrm{h}_{\mathrm{i}}=\text { constant }
$$

with $\mathrm{h}_{\mathrm{i}}$ is coefficient of $\mathrm{X}_{\mathrm{i}}$ in the total energy (potential and kinetic) of the robot.

b-An inertial parameter $X_{i}$ can be regrouped to some others $X_{i 1}, \ldots, X_{i r}$ if :

$$
\mathrm{h}_{\mathrm{i}}=\sum_{\mathrm{p}=\mathrm{i}_{1}}^{\mathrm{i}_{\mathrm{r}}} \alpha_{\mathrm{p}} \mathrm{h}_{\mathrm{p}}+\text { constant }
$$

where $\alpha_{\mathrm{p}}$ is constant.

In this case the parameter $X_{i}$ can be eliminated while the parameters $X_{i 1}, X_{i 2}, \ldots X_{i r}$, will be replaced by $\mathrm{XR}_{\mathrm{p}}=\mathrm{X}_{\mathrm{p}}+\alpha_{\mathrm{p}} \mathrm{X}_{\mathrm{i}}$. In this case we say that $\mathrm{X}_{\mathrm{i}}$ has been regrouped to $\mathrm{X}_{\mathrm{i} 1}, \ldots, \mathrm{X}_{\mathrm{ir}}$. Conditions (2) and (3) are equivalent to conditions (4) and (5) in [1].

It has been pointed out in [1] that the inertial parameters satisfying condition (2) belong to the links near the base side, some results which permit to calculate most of these parameters without the calculation of the energy are also given in [1]. These results will be completed in this correspondence.

Relations (15) and (16) of the paper of Gautier and Khalil [1] permit to regroup the parameters $Y_{j}, m Z_{j}$ and $m_{j}$ if joint $j$ is rotational and $X X_{j}, X Y_{j}, X Z_{j}, Y Y_{j}, Y Z_{j}, Z Z_{j}$ if joint $j$ is translational. This result gives most of the minimum inertial parameters.

Supposing that $r_{1}$ is the first rotational joint and $r_{2}$ is the first rotational joint not parallel to $r_{1}$ more parameters may be regrouped. Partial results are given in [1] if the joint axes between $r_{1}$ and $r_{2}$ are either parallel or perpendicular. In this comment the general results will be given.

\section{II- Particular regrouping of the inertial parameters between r1 and r2}

Two cases are to be considered:

a- the axis of a translational link $\mathrm{j}$ is not parallel to the axis of $\mathrm{r} 1$ for $(\mathrm{r} 1<\mathrm{j}<\mathrm{r} 2)$

Noting that the projection of $\mathbf{h}_{\mathrm{mSj}}=\left[\begin{array}{llll}\mathrm{h}_{\mathrm{mXj}} & \mathrm{h}_{\mathrm{mYj}} & \mathrm{h}_{\mathrm{mZj}}\end{array}\right]$ on the axis of joint $\mathrm{r}_{1}$ is constant, the following linear relation is obtained :

$$
\mathrm{ja}_{\mathrm{ar} 1} \mathrm{~h}_{\mathrm{mXj}}+\mathrm{j}_{\mathrm{ar} 1} \mathrm{~h}_{\mathrm{mYj}}+\mathrm{j}_{\mathrm{zr} 1} \mathrm{~h}_{\mathrm{mZj}}=\mathrm{constant}
$$

where $\mathrm{j}_{\mathbf{a}_{\mathrm{r} 1}}=\left[\begin{array}{lll}\mathrm{j}_{\mathrm{a}_{\mathrm{xr} 1}} & \mathrm{j}_{\mathrm{a}_{\mathrm{yr} 1}} & \mathrm{j}_{\mathrm{zr}}\end{array}\right]^{\mathrm{T}}$ is the unit vector of link $\mathrm{r}_{1}$ axis referred to frame $\mathrm{j}$. The regrouping relation or elimination are given in table 1 . 


\begin{tabular}{|c|c|c|c|}
\hline $\mathrm{j}_{\mathrm{zr} 1} \neq 0$ & $\mathrm{j}_{\mathrm{z}} \mathrm{zr}=0, \mathrm{j}_{\mathrm{xr} 1} \mathrm{j}_{\mathrm{a}_{\mathrm{yr} 1}} \neq 0$ & $\mathrm{j}_{\mathrm{zr} 1}=0, \mathrm{j}_{\mathrm{xr} 1}=0$ & $\mathrm{j}_{\mathrm{a}_{\mathrm{zr} 1}}=0, \mathrm{j}_{\mathrm{ar} 1}=0$ \\
\hline $\begin{array}{l}\mathrm{mXR}_{\mathrm{j}}=\mathrm{mX}_{\mathrm{j}}-\frac{\mathrm{j}_{\mathrm{ar} 1}}{\mathrm{ja}_{\mathrm{zr} 1}} \mathrm{mZ} \\
\mathrm{mYR}_{\mathrm{j}}=\mathrm{mY} \mathrm{Y}_{\mathrm{j}}-\frac{\mathrm{j}_{\mathrm{a}_{\mathrm{yr} 1}}}{\mathrm{ja}_{\mathrm{zr} 1}} \mathrm{mZ}\end{array}$ & $m X_{j}=m X_{j}-\frac{j_{a_{x r} 1}}{\mathrm{ja}_{y r 1}} m Y$ & $m Y_{j}=0$ & $\mathrm{mX}_{\mathrm{j}}=0$ \\
\hline
\end{tabular}

Table 1

This mean that a parameter will be always regrouped or has no effect on the dynamic model in this case.

b) the axis of a translational link $\mathrm{j}$ is parallel to the axis of $\mathrm{r} 1$ for $(\mathrm{r} 1<\mathrm{j}<\mathrm{r} 2)$

The following two results are given:

$\mathrm{i}$ - As the $\mathrm{x}$ and $\mathrm{y}$ rotational velocity componentes of link $\mathrm{j}$ are equal to zero then $\mathrm{mZ}_{\mathrm{j}}$ has no effect on the dynamic model.

ii- Assuming the nearest rotational joint for $\mathrm{j}$ to the base side is $\mathrm{i}$, then the following relation between $\mathbf{h}_{\mathrm{msj}}$ and $\mathbf{h}_{\mathrm{msj}-1}$ is obtained:

$$
\mathbf{h}_{\mathrm{mSj}}^{\mathrm{T}}=\mathrm{j}_{\mathbf{A}_{\mathrm{j}-1}} \mathbf{h}_{\mathrm{mSj}-1}^{\mathrm{T}}-\left[\begin{array}{lll}
2 \mathrm{P}_{\mathrm{x}} \mathrm{h}_{\mathrm{ZZi}} & 2 \mathrm{P}_{\mathrm{y}} \mathrm{h}_{\mathrm{ZZi}} & 0
\end{array}\right]^{\mathrm{T}}
$$

with:

$$
\mathrm{jP}_{\mathrm{j}-1}=\left[\begin{array}{lll}
\mathrm{P}_{\mathrm{x}} & \mathrm{P}_{\mathrm{y}} & \mathrm{P}_{\mathrm{z}}
\end{array}\right]^{\mathrm{T}}=\left[\begin{array}{lll}
-\mathrm{d}_{\mathrm{j}} \mathrm{C} \theta_{\mathrm{j}} & \mathrm{d}_{\mathrm{j}} \mathrm{S} \theta_{\mathrm{j}} & -\mathrm{r}_{\mathrm{j}}
\end{array}\right]^{\mathrm{T}}
$$

thus, the parameters $m X_{j}$ and $m Y_{j}$ can be regrouped using the following relations:

$$
\begin{aligned}
& m X_{j-1}=m X_{j-1}+C \theta_{j} m X_{j}-S \theta_{j} m Y_{j} \\
& m \mathrm{mR}_{\mathrm{j}-1}=\mathrm{mY} Y_{\mathrm{j}-1}+\mathrm{S} \theta_{\mathrm{j}} \mathrm{C} \alpha_{\mathrm{j}} \mathrm{mX_{j }}+\mathrm{C} \theta_{\mathrm{j}} \mathrm{C} \alpha_{\mathrm{j}} \mathrm{mY} \mathrm{Y}_{\mathrm{j}} \\
& m Z R_{j-1}=m Z_{j-1}+S \theta_{j} S \alpha_{j} X_{j}+C \theta_{j} S \alpha_{j} m Y_{j} \\
& Z Z R_{i}=Z Z_{i}+2 d_{j} C \theta_{j} m X_{j}-2 d_{j} S \theta_{j} m Y_{j}
\end{aligned}
$$

where $\alpha_{j}, d_{j}, r_{j}, \theta_{j}$ are the geometric parameters defining frame $\mathrm{j}$ with respect to frame $\mathrm{j}-1$ according to the modified Denavit and Hartenberg notations [3].

\section{III.Practical Calculation of the minimum parameters}

The following rules permit to define all the parameters which will be regrouped or eliminated, the rest of the parameters constitute the minimum inertial parameters (base or identifiable parameters) of the dynamic model. 
1- Use the general regrouping relations (15) and (16) in [1] to eliminate the following parameters:

$a-Y Y_{j}, m Z_{j}, m_{j}$ if joint $j$ is rotational for $j=n, \ldots 1$,

$b-X X_{j}, X Y_{j}, X Z_{j}, Y Y_{j}, Y Z_{j}, Z Z_{j}$, if joint $j$ is translational for $j=n, \ldots 1$,

2- Eliminate $\mathrm{mZ}_{\mathrm{j}}$ and regroup $m \mathrm{X}_{\mathrm{j}}$ and $m \mathrm{Y}_{\mathrm{j}}$ using (6) if $\mathrm{j}$ is translational and $\mathbf{a}_{\mathrm{j}} / / \mathbf{a}_{\mathrm{r} 1}$ for $\mathrm{r}_{1}<\mathrm{j}$ $<\mathrm{r}_{2}$

3- Regroup or eliminate one of the parameters $m X_{j}, m Y_{j}, m Z_{j}$, if $\mathbf{a}_{r 1}$ is not parallel to $\mathbf{a}_{j}$, and $\mathrm{j}$ is translational and $\mathrm{r}_{1}<\mathrm{j}<\mathrm{r}_{2}$, using table 1 .

4- Eliminate $\mathrm{XX}_{\mathrm{j}}, \mathrm{XY}_{\mathrm{j}}, \mathrm{XZ}_{\mathrm{j}}, \mathrm{YZ}_{\mathrm{j}}$ if $\mathrm{j}$ is rotational and $\mathrm{r}_{1} \leq \mathrm{j}<\mathrm{r}_{2}$ ( the axes of these joints are parallel to $r_{1}$ ). It is to be noted that $Y_{1}$ has also been eliminated in rule 1 .

5- Eliminate $\mathrm{mX}_{\mathrm{j}}, \mathrm{mY}_{\mathrm{j}}$, they have no effect when $\mathrm{j}$ is rotational for $\left(\mathrm{r}_{1} \leq \mathrm{j}<\mathrm{r}_{2}\right)$ and $\left(\mathbf{a}_{\mathrm{j}}\right.$ is along $\left.\mathbf{a}_{\mathrm{r} 1}\right)$ and $\left(\mathbf{a}_{\mathrm{r} 1} / / \mathbf{a}_{\mathrm{i}} / /{ }^{0} \mathbf{g}\right.$ for all $\left.\mathrm{i}<\mathrm{j}\right)$. With ${ }^{0} \mathbf{g}$ denotes the acceleration of gravity with respect to frame 0 . It is to be noted that $\mathrm{mZ}_{\mathrm{j}}$ has also been eliminated in rule 1 .

6- Eliminate $\mathrm{mX}_{\mathrm{j}}, \mathrm{mY}_{\mathrm{j}}, \mathrm{mZ}_{\mathrm{j}}$ they have no effect, when $\mathrm{j}<\mathrm{r}_{1}$ (they represent the translational links before $r_{1}$, where the angular velocity is equal to zero) .

The main advantage of this method with respect to recently proposed method [4], is that the given minimum parameters can be used directly in classical Newton-Euler algorithm to calculate the dynamic model. The given results complete also the algorithm calculating the minimum inertial parameters of tree structure robots given in [5] such that all the minimum parameters can be obtained directly.

\section{$\underline{\text { References }}$}

[1] M. Gautier, W. Khalil, " Direct Calculation of Minimum Set of Inertial Parameters of Serial Robots", IEEE Transactions on robotics and Automation, Vol. 6, NO.3, June 1990, pp. 368-373.

[2]Khalil W., Kleinfinger J.-F., "Minimum operations and minimum parameters of the dynamic model of tree structure robots", IEEE J. of Robotics and Automation, Vol. RA3(6), 1987, p. 517-526.

[3]Khalil W., Kleinfinger J.-F., "A new geometric notation for open and closed-loop robots", Proc. IEEE Conf. on Robotics and Automation, San Francisco, 1986, p. 1174-1180.

[4] S.K Lin, "An Identification Method for Estimating the Inertia Parameters of a Manipulator", Journal of Robotic Systems 9(4), 505-528, 1992

[5] W.Khalil, F. Bennis, M. Gautier, " Calculation of the minimum inertial parameters of tree structure robots" 3d ICAR Conference, Columbus, June, 1989, pp. 189-201. 